of public education to put people's fears at rest. Lord Halsbury, the chairman of the committee which recommended that the pound rather than ten shillings should be used as the basic unit, backed up the government with the argument that the choice of the pound would ensure that people were not cluttered up with "unwanted coins". And Lord Shackleton, opening a debate on the subject for the government, said that, even though he welcomed the opportunity for discussion, it should be clear that "the government had made up its mind".

\section{University Money}

THE University Grants Committee this year combines its annual report with the review of university development in Britain in the first four years of the present quinquennium from 1962-64 (H.M.S.O., Cmnd. 3192, 4s.). The committee, now twenty-one strong and on a part-time basis, rejects suggestions that it should be radically reduced in size and made professional. Its present size is "probably about right". The U.G.C. now has more sub-committees from which it can seek advice; new ones, covering Arts, Audio-Visual Aids, Biological Sciences, Education, Mathematics, Physical Sciences and Social Studies, have been set up.

The new quinquennium-the five-year period for which the U.G.C. establishes grants-begins on August 1, 1967. Grants for the whole period will not be announced for several months, but a provisional announcement has already been made of the minimum level of the recurrent grant in the first year of the quinquennium. On December 20, 1965, the Secretary of State for Education and Science said that the recurrent grant (which excludes capital investment in building and equipment) would be $£ 147.5$ million. This figure excludes the cost to the U.G.C. of taking over certain research projects from the research councils and also a contribution of roughly $£ 6$ million which the central government will eventually make towards local authority rates (taxes). The comparable figure for 1966-67 is $£ 133.2$ million, which implies an increase of 10.7 per cent. The U.G.C. has now allocated this sum to the individual universities so that they can plan their recruitment of staff for 1967-68 and also indulge in more elaborate forward planning if they are so inclined. The U.G.C. is plainly hoping to encourage the universities to make fuller use of modern management techniques. Organization and method can hardly be said to be spreading like wildfire through the British universities, though, and the U.G.C. has enlisted the Committee of Vice-Chancellors and Principals to fan the flames. Organization and method exercises have been mounted in north-east England and in Scotland; several other universities, the report hints, are about to take the plunge.

The report also announces a new type of grant which should be available in 1968-69, if any university is thinking ahead that far. This will be an equipment grant, designed to enable universities with old departments to re-equip them occasionally. At present new equipment is supplied with new buildings, so that university departments tend to be either new from top to bottom, or antique both in fabric and equipment. Most, of course, have been buying equipment piecemeal from their recurrent grants, but the new proposals would make special grants available for this purpose.
After the publication of the report, Sir John Wolfenden, chairman of the U.G.C., suggested that an investigation of the way university laboratories are used might well be profitable. Once again the U.G.C. is nominating the Committee of Vice-Chancellors and Principals for the job, in collaboration with the Confederation of British Industries. (The investigation would be on the same lines as that conducted by Sir Gordon Sutherland and his committee into government laboratories, which will shortly be published.) Sir John Wolfenden also said that universities which are deterred from undertaking research contracts from industry because these are short-term operations should get in touch with the U.G.C., which will occasionally be prepared to take over in the same way as it has been doing for contracts with the research councils.

\section{Nottingham Agriculture}

THE University of Nottingham has decided to amalgamate the departments of agriculture and horticulture into one "Faculty of Agricultural Science". This decision will no doubt bring cheer to the University Grants Committee, which has recently been attempting to encourage the rationalization of agricultural teaching at British universities. The registrar at Nottingham, Mr. A. Plumb, explained earlier this week that the university had suggested a "re-alignment" in view of the imminent departure of the professor of agriculture, Dr. J. P. Hudson, for Bristol, and had not had to wait for prompting from the U.G.C. A statement by the university says that the present department of agricultural sciences will be divided into two-a department of physiology and environmental studies and a department of applied biochemistry and nutrition. This will emphasize the increasingly scientific character of agricultural education. The school of agriculture at Nottingham is in fact the second largest in Britain with an entry of 93 undergraduates in 1965-66 and with five professors, two readers and 26 lecturers on the staff. The department of agricultural economics will be unaffected by the proposed change.

\section{Living on Air}

A Boost in British hovercraft development may result from a decision announced by the Minister of Technology, Mr. Anthony Wedgwood Benn, on January 24. The Technical Group of Hovercraft Development Ltd., a subsidiary of the National Research Development Corporation, is on April 1 to become the responsibility of the National Physical Laboratory. Almost all the activities of Hovercraft Development Ltd. were concentrated in the Technical Group at Hythe, so that NRDC is left with little but the power to issue licences for hovercraft development. The move seems sensible if only to make use of the considerable experience of the Ship and Aerodynamics Divisions at the NPL; the Ship Division has been working on air cushion vehicles for some time, both in collaboration with HDL and on its own account. The performance of free flight models in waves has been studied, in experiments dosigned to be of direct value to hovercraft engineers. A constant force towing dynamometer using a slipping clutch has been designed, allowing the model to surge $30 \mathrm{ft}$. downstream quite freely, and minimizing the risk that it will overturn. 